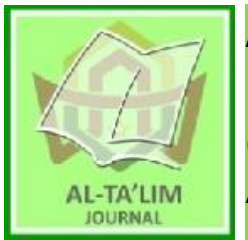

AL-TA'LIM JOURNAL, 27 (2), 2020, (115-126)

(Print ISSN 1410-7546 Online ISSN 2355-7893)

Available online at http://journal.tarbiyahiainib.ac.id/index.php/attalim

\title{
The Reconstruction of Indigenous Knowledge about Golobe (Hornstedtia alliacea) as a Natural Resource Conservation Study for Prospective Teachers' Scientific Literacy
}

Received: $20^{\text {th }}$ February 2020; Revised: $15^{\text {th }}$ April 2020; Accepted: $30^{\text {th }}$ June 2020

Permalink/DOI: http://dx.doi.org/10.15548/jt.v27i2.610

\section{Parmin *)}

Universitas Negeri Semarang, Indonesia.

E-mail: parmin@mail.unnes.ac.id

\section{Fidia Fibriana}

Universitas Negeri Semarang, Indonesia.

E-mail: fibriana.f@mail.unnes.ac.id

*) Corresponding Author

\begin{abstract}
This study intended to measure prospective science teachers' scientific literacy through a conservation course on a natural resource topic. The natural source as the research object was golobe, an endemic plant in Maluku which has been consumed as the traditional medicine by the local community, which was studied for its chemical properties. Golobe is believed to have the properties to cure diseases. The lab testing revealed that golobe contains alkaloids, flavonoids, terpenoids, steroids, polyphenols, antioxidants and antibacterial properties. The scientific knowledge based on the lab report was reconstructed using the Science Integrated Learning (SIL) model. The obtained laboratory test results were matched up with the indigenous knowledge of the golobe. The indigenous knowledge of local community on golobe was converted to be the scientific knowledge. Then, the result of reconstruction was applied as the basis of Conservation Education course material development. The research target included prospective science teachers joining the Conservation Education course. The assessed scientific literacy consisted of (1) knowing scientific questions; (2) exploring; (3) identifying scientific evidence; (4) laboratory work; (5) drawing up conclusions; (6) communicating, and (7) demonstrating. Prospective teachers have owned the seven components of scientific literacy after studying natural resource conservation materials. The research concluded that the use of the knowledge reconstruction of Golobe in the North Loloda Tribe, North Maluku, Halmahera Archipelago has an impact on the development of prospective teachers' scientific literacy.
\end{abstract}

Keywords: Reconstruction; indigenous knowledge; conservation; scientific literacy; prospective teachers.

How to Cite: Parmin, P., \& Fibriana, F. (2020). The Reconstruction of Indigenous Knowledge about Golobe (Hornstedtia alliacea) as a Natural Resource Conservation Study for Prospective Teachers' Scientific Literacy. Al-Ta lim Journal, 27(2). doi:https://doi.org/10.15548/jt.v27i2.610

\section{INTRODUCTION}

This study was initiated by
preliminary research, in which the
information about indigenous knowledge of
native tribes living in the frontier, outermost,
and least developed regions (known as $3 \mathrm{~T}$
regions) was collected. The information was

gathered during field observation to delve the traditions uphold by the inlanders. One of the tribes targetted was North Loloda Tribe in North Maluku, Halmahera Archipelago. Interviews with the community revealed that they believe in the benefits of golobe to cure, yet young inlanders have started to leave the tradition. In addition, modern medicine, 
which is more practical, is getting available in the region. This fact marks the threat of the tradition's existence. Moreover, the plant has now begun to be hard to find. This was underlied by the young generations' nescience of the plant's benefits to health. Therefore, it is necessary to reconstruct the indigenous knowledge about golobe into scientific information. This is parallel with Robbins \& Dewar'sopinion (2011), stating that the process of transforming traditional knowledge into scientific knowledge is needed in order to make it acceptable. Similarly, Woro, et al. (2016) elucidated that reconstructing people's endangered indigenous knowledge is a meaningful way to conserve natural resources.

Anxiety about the potential loss of Indonesia's original knowledge is the background of conservation studies for prospective science teachers. Every prospective science teacher at Universitas Negeri Semarang studies conservation as a compulsory subject, which is one of the efforts to preserve Indonesia's natural resources. This is similar to Wang, et al. (2016), who explained that conservation is a form of awareness about the importance of preserving nature. Conservation study needs to be enriched with the results of the reconstruction of original knowledge so that awareness is expected to arise from prospective science teachers. The use of the reconstruction results is a form of real action for conservation, which is not limited to saving but preserving.

Golobe belongs to genus Hornstedtia, a member of the Zingiberaceae family. The plant is preferred for having sweet and sour fruit that could be consumed fresh. Geographically, golobe could grow in Indonesian wilderness rich in humus, particularly Sumatra and Borneo. It has a favorable adaptation and is possibly cultivated, mainly to preserve it from extinction. As people's awareness of golobe's scientific benefit raises, the cultivation will be more natural to perform.

This traditional truth cannot be studied as a scientific knowledge since it is built based on ancestors' heredity. Thus, it has to be examined scientifically to generate rigorous information that could be referred to as academic materials learned in colleges. To realize it, a testing process of chemical compounds is required. This is parallel with Chaudhuri (2015), who asserted that accurate information is arranged from scientific testing results. Moreover, Higgins \& Kim (2019) argued that research is needed to conduct a study of theories and information about indigenous knowledge. In addition, the research results on indigenous knowledge should be immediately integrated into the science education field ( $\mathrm{H} \mathrm{ng}$, et al. 2017; Ryan, 2008; \& Vass, et al. 2019).

\section{According to Archer-Bradshaw} (2017), scientific literacy is needed for analytical thinking skills. Each prospective science teacher is required to be scientifically literate, which is indicated by his/her skills in designing research, implementing research, drawing up conclusions, and communicating research results (Rhee\& Choi, 2014; Hanuscin \& Zangori, 2016). However, the Programme for International Student Assessment (PISA) revealed that Indonesian learners remain to have low-level scientific literacy. They could not perform an analysis, which means that school learning has not been able to achieve the expected literacy. On the other hand, prospective science teachers play a significant role in building their future students' favorable scientific literacy, yet beforehand, they have to construct their scientific literacy at college.

Allchin (2014) and Hwanget al. (2018) performed an analysis of scientific literacy and revealed that strong literacy is based on the ability to analyze learning resource containing concrete facts. Hence, supplying students with real object study is exceedingly essential. This fact is strengthened by Archer-Bradshaw (2017) andShe et al., (2018), who asserted that literacy is built from personal knowledge developed through practices in making a decision. Chances to discover science concepts could give a positive impact on 
scientific literacy, as disclosed by Yarden (2009) and Trauth-Nare (2016) that literacy set up through broad access to knowledge and continued to debating and discussing of findings would give a positive assessment of science. Besides, teachers' selection of learning strategy and sources also give credits to the achievement of learning objectives. Further, Inventado et al. (2018) andHsieh, et al., (2019)ensured that learning strategies equipped with contextual learning resources related to environment and community life are more likely to foster scientific literacy.

This research intended to measure the scientific literacy of prospective teachers through the study of conservation on the natural resource topic. The conservation learning utilized the findings of laboratory testing results from Golobe plants. The measured scientific literacy referred to the 2000 PISA, which was modified by the addition of exploration components and laboratory work skills. Both components were inserted to scientific literacy since they are needed as a stage of reconstruction of indigenous knowledge into scientific knowledge. The measured scientific literacy includes seven components: knowing scientific questions, exploring, identifying scientific evidence, laboratory work, drawing up conclusions, communicating, and demonstrating.

Table 1. Modification of Scientific Literacy Components

\begin{tabular}{l} 
Scientific Literacy (PISA) \\
\hline 1. Getting to know scientific questions \\
3. Identifying evidence needed in scientific \\
investigations \\
5. Drawing up and evaluating conclusions based \\
on evidence \\
6. Communicating valid conclusions \\
7. Demonstrating an understanding of scientific \\
concepts
\end{tabular}

\section{METHOD}

This study employed a qualitative approach in which the data were analyzed descriptively, referring to Sugiyono (2008). On the other hand, the reconstruction of indigenous knowledge made use of SIL (Science Integrated Learning) model adverting to Parmin et al., (2017) consisting of six stages: exploration, concept integration, experiment (lab testing), analysis, actiontaking, and reflection. The exploration focused on the golobe plant, ensuring that the exploration results are genuinely based on the community's knowledge that is related to the science concept. Laboratory tests are carried out as part of the scientific knowledge testing. Analysis of the lab test results was done, aiming at arranging academic script for a learning source. The decision towards the analysis results was taken to determine the Modification of Scientific Literacy for this Study

1. Getting to know scientific questions

2. Exploring the community's indigenous knowledge

3. Identifying evidence needed in scientific investigations

4. Laboratory work for material testing

5. Drawing up and evaluate conclusions based on evidence

6. Communicating valid conclusions

7. Demonstrating an understanding of scientific concepts

form of scientific knowledge. Finally, reflection was performed to obtain feedback from prospective science teachers on the learning materials used in the conservation course.

The research targets included eightysix prospective science teachers joining the conservation course. Several students from the Indonesian higher education affirmation program who come from the Maluku region were also included in this study. The Malukunese students were involved starting from identifying the indigenous knowledge about Golobe, finding the plants in their home regions, and taking plants to be tested in the laboratory. The laboratory testing of Golobe plants was carried out at the Universitas Negeri Semarang's organic chemistry laboratory. These flows are depicted in Figure 1. 


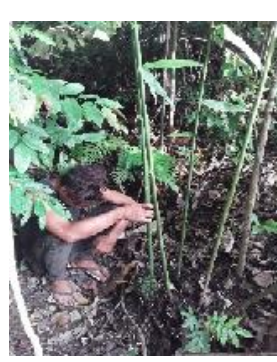

(a)

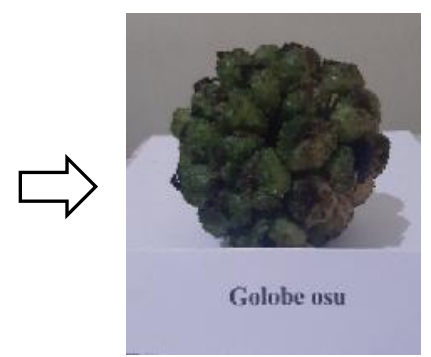

(b)

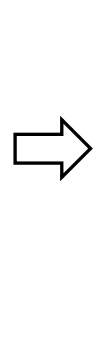

Information:

(a) Golobe plant in the forest

(b) Golobe fruit

(c) Testing process

(d) Testing results

Figure 1:Stages of Laboratory Test on Golobe

Field observation, interview, and documentation were done to explore the golobe and community's knowledge about it. The field observation resulted in a sampling of golobe, which was then identified its type and characteristics. In order to gather information about the indigenous knowledge, interviews were carried out with the North Loloda tribe settling in the North Maluku, Halmahera Archipelago. Generally, the interviews were opened for three main questions: (1) how long have you known that this plant is believed to cure various diseases?; (2) how do you consume it?; and (3) why are you sure that this plant cures diseases?. Documentation through picture and video taking was carried out to evidence that the exploration stage has been done in this research.

The primary data of this research was the lab testing results on the golobe's compound, which includes flavonoid serving as antioxidant and antibacterial activity. A phytochemical screening test was brought about to examine the flavonoid compound (Odeja et al., 2017). The sample was cleaned, dried, and ground to obtain golobe powder. The powder was dissolved, and added methanol then boiled for about 25 minutes. The next step was filtering the solution, and the solvent was evaporated to dryness. The golobe extract was shaken vigorously using chloroform, and distilled water was added to form two layers. The water layer is divided into 3 (three) parts: 1) 2 drops of $1 \% \mathrm{FeCl}_{3}$ were put in the first layer, if the solution is blackened, then it contains flavonoid; 2) 2 drops of $10 \% \mathrm{NaOH}$ were put in the second layer, if the solution produces a bluish-green color, then it contains flavonoid

The antioxidant activity test employed the DPPH method (2,2-diphenyl-1picrylhydrazyl) (Ghosh et al., 2015). A total of $25 \mathrm{mg}$ of crude golobe extract was weighed then dissolved in a $25 \mathrm{ml}$ volumetric flask with methanol. The mother liquor was pipetted in $0.1 \mathrm{ml} ; 0.2 \mathrm{ml} ; 0.3 \mathrm{ml}$; and $0.4 \mathrm{ml}$ into a $25 \mathrm{ml}$ volumetric flask to obtain the test solution concentration of $4 \mathrm{ppm}, 8 \mathrm{ppm}, 12$ $\mathrm{ppm}$, and $16 \mathrm{ppm}$. To each volumetric flask, 5 $\mathrm{ml}$ of $0.5 \mathrm{~mm}$ DPPH solution was added in, and the volume was met to the outline by methanol. DPPH absorbance was measured with a visible light spectrometer at a wavelength of $515 \mathrm{~nm}$, at intervals of 5 minutes to 30 minutes. The antioxidant power was measured as a decrease in the absorption of DPPH solutions due to the addition of samples. The DPPH solution uptake values before and after the addition of the extract were calculated as percent inhibition (\% inhibition) using the following formula: $\%$ inhibition $=\{(\mathrm{A}$ control $-\mathrm{A}$ sample $)\} / \mathrm{A}$ control x $100 \%$.

The antibacterial activity test, referring to Masoko \& Makgapeetja (2015), was performed with several preparations including bacterial rejuvenation, creating bacterial suspensions, making paper discs, 
preparing negative and positive controls, and making series of concentrations, i.e., 100; 300; and $500 \mathrm{mg} / \mathrm{mL}$. A Disc Diffusion method (Kirby-Bauer Test) was undertaken for the antibacterial activity test. The bacterial suspension test, as much as $20 \mathrm{~L}$, was put into the media in petri dish then rubbed with a sterile cotton swab over the media. The swab was rotated several times, and the procedure was repeated twice. The positive control of Ciprofloxacin $50 \mathrm{~g}$ and the negative control of 20\% DMSO were placed on a paper disc. Then, the paper disc was settled on the surface of the media according to the desired position. Next, the media was incubated at $37^{\circ} \mathrm{C}$ for 24 hours, then the diameter of the inhibition zone was measured using the calipers expressed in millimeters.

The results of laboratory testing were then used to make academic texts in the form of learning materials for conservation learning. Prospective teachers' scientific literacy data were gathered through observation sheets. The measured scientific literacy comprised seven components consisting of: knowing scientific questions, exploring, identifying scientific evidence, laboratory work, drawing up conclusions, communicating, and demonstrating. The criteria for determining the scientific literacy referred to Arikunto's (2012) with a range of scores and categories including 80-100 (excellent), 61-80 (good), 41-60 (fair), and 21-40 (less). Interviews with prospective teachers were also conducted to obtain their feedback after using the reconstruction outcomes in conservation learning.

\section{RESULTS AND DISCUSSIONS}

The results of laboratory tests on the Golobe are shown in Table 2.

Table 2. The Testing Results of Golobe Based on Alkaloid, Flavonoid, Terpenoid, Steroid, and Polyphenol

\begin{tabular}{|c|c|c|c|}
\hline \multicolumn{4}{|c|}{ Parameters } \\
\hline Plant & Parameter & Test Result & Methods \\
\hline \multirow[t]{4}{*}{ GolobeOsu } & Alkaloid & + & Phytochemical \\
\hline & Flavonoid & + & screening \\
\hline & Terpenoid & + & \\
\hline & Polyphenol & + & \\
\hline \multirow[t]{4}{*}{ GolobeSusu } & Alkaloid & + & Phytochemical \\
\hline & Flavonoid & + & screening \\
\hline & Terpenoid & + & \\
\hline & Polyphenol & + & \\
\hline \multirow[t]{4}{*}{ GolobeGogitiwili } & Alkaloid & + & Phytochemical \\
\hline & Flavonoid & + & screening \\
\hline & Terpenoid & + & \\
\hline & Polyphenol & + & \\
\hline
\end{tabular}

The experimental results on three types of golobe unveiled that all of them contain alkaloid, flavonoid, terpenoid, steroid, and polyphenol. Conceptually, the alkaloid compound is rarely found in plants. This is in contrast to the flavonoid, which is widely found in certain types of plants. Alkaloid, flavonoid, and polyphenol work as antioxidant agents which prevent humans from chronic diseases (Khodabande, et al. 2017). Terpenoid, on the other hand, serves an antibacterial agent that cures microorganism infection. It is similar to the steroid, which can fasten the wound healing process. In other words, the testing outcomes confirmed the community's indigenous knowledge that consuming golobe would be beneficial for health.

Tabel 3. The Testing Results of Golobe Based on Antioxidant Activities

\begin{tabular}{llll}
\hline \multicolumn{1}{c}{ Plant } & \multicolumn{1}{c}{ Parameter } & $\begin{array}{c}\text { Test } \\
\text { Result }\end{array}$ & Methods \\
\hline GolobeOsu & Antioxidant Activity (IC50) & 6,1267 & \\
GolobeSusu & Antioxidant Activity (IC50) & 6,8763 & DPPH \\
GolobeGogitiwili & Antioxidant Activity (IC50) & 5,7821 & \\
\hline
\end{tabular}


The test results have justified the trust of communities who have been consuming this plant.

Table 4. The Testing Results of Golobe Based on Staphylococcus aureusAntibacterial Activities

\begin{tabular}{|c|c|c|c|c|}
\hline Plant & Parameter & $\begin{array}{l}\text { Concentration } \\
(\mathrm{mg} / \mathrm{mL})\end{array}$ & $\begin{array}{l}\text { Inhibition zone } \\
(\mathrm{mm})\end{array}$ & Methods \\
\hline GolobeOsu & $\begin{array}{l}\text { Staphylococcus } \\
\text { aureusAntibacterial }\end{array}$ & $\begin{array}{l}100 \\
300\end{array}$ & $\begin{array}{c}9,24 \pm 0,18 \\
11,15 \pm 0,44\end{array}$ & $\begin{array}{l}\text { Disc Diffusion } \\
\text { (Kirby- }\end{array}$ \\
\hline GolobeSusu & $\begin{array}{l}\text { Staphylococcus } \\
\text { aureusAntibacterial }\end{array}$ & $\begin{array}{l}100 \\
300\end{array}$ & $\begin{array}{l}10,02 \pm 0,25 \\
11,23 \pm 0,33\end{array}$ & BauerTest) \\
\hline GolobeGogitiwili & $\begin{array}{l}\text { Staphylococcus } \\
\text { aureusAntibacterial }\end{array}$ & 100 & $10,44 \pm 0,23$ & \\
\hline
\end{tabular}

Golobe is also believed to heal wounds on human skin, and this underlies the analysis of antibacterial agents. The experiments on three types of golobe at a concentration of $100 \mathrm{mg} / \mathrm{mL}$ and $300 \mathrm{mg} / \mathrm{mL}$ have positively found an inhibition zone to Staphylococcus aureus, which is the answer to the golobe's ability to cure wounds. These stages of research were evidenced by the prospective science teachers, in which during the learning activities, seven components of scientific literacy were assessed. The assessment data on 86 prospective science teachers are presented in Figure 2.

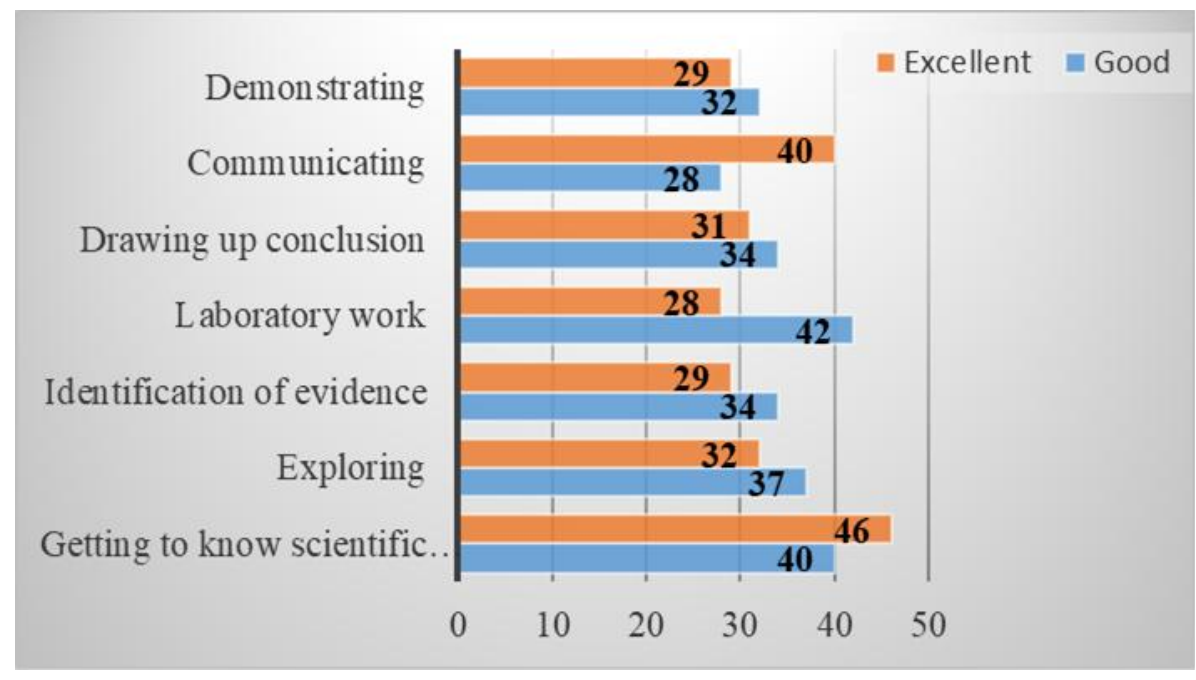

Figure 2: The Assessment Results of the Prospective Teacher's Scientific Literacy

The assessment revealed that there were $69(80 \%)$ prospective teachers that could explore the community's indigenous knowledge based on the assigned task. Moreover, 63 (73\%) of them favorably identified the evidence required in the research. For the lab work, $70(81 \%)$ student teachers possessed a remarkable skill in testing the research object. Also, there were $65(76 \%)$ prospective teachers who drew up conclusions well. Besides, there are respectively 68 and 61 student teachers who competently communicated and demonstrated the research results. After being rated, it was found out that the average of the seven components reached 82 or categorized as excellent.

The prospective science teachers experienced numerous learning activities in the conservation course. The designed learning activities were linked to modified 
Table 5. Learning Activities in Conservation Course

\begin{tabular}{|c|c|}
\hline Learning Activities & Scientific Literacy (Modified) \\
\hline $\begin{array}{l}\text { Gathering information from the internet and is strengthened } \\
\text { by asking resource persons }\end{array}$ & Getting to know scientific questions \\
\hline $\begin{array}{l}\text { Watching original images and video footage about people's } \\
\text { habit in seeking and consuming golobe, documented by the } \\
\text { research team in the exploration process. }\end{array}$ & $\begin{array}{l}\text { Exploring the community's indigenous } \\
\text { knowledge }\end{array}$ \\
\hline $\begin{array}{l}\text { Registering information and facts obtained to determine } \\
\text { primary evidence about the savor of Golobe }\end{array}$ & $\begin{array}{l}\text { Identifying evidence needed in scientific } \\
\text { investigations }\end{array}$ \\
\hline $\begin{array}{l}\text { Listening to the experimental video showing the lab testing } \\
\text { process }\end{array}$ & Laboratory work for material testing \\
\hline Using the test result data to make conclusions & $\begin{array}{l}\text { Drawing up and evaluate conclusions based on } \\
\text { evidence }\end{array}$ \\
\hline Presenting the assignment outturns in groups & Communicating valid conclusions \\
\hline Informing the scientific concepts related to Golobe testing & $\begin{array}{l}\text { Demonstrating an understanding of scientific } \\
\text { concepts }\end{array}$ \\
\hline
\end{tabular}

Golobe conservation is urgently
needed keeping in mind the golobe's favorable benefits, yet it is prone to extinction. Similarly, Wyborn et al. (2016) andNtuli, et al. (2019) asserted that conservation could be implemented through counseling to the local community. In this case, golobe conservation should not be accomplished only to the local community but also to people in general. The dissemination of research results has to be done, and one of the best ways is through learning. The knowledge obtained by the prospective science teachers during the conservation course will be passed through their future teachers; in other words, it is a long-term dissemination process. This fact is supported by Rhee \& Choi (2014), who argued that future teachers are the proper disseminator for continuing spreading. This study's outturns also strengthen the importance of indigenous knowledge conservation, which, if not being done, will be the loss of Indonesian as well as the world's citizens. This is aligned to Sukri et al. (2018) andGroves (2019), who elucidated that the extinction of both natural resources and indigenous knowledge will affect a nation's identity. That being said, this research has taken part in the conservation of the two aspects.

The scientific literacy constructed during the learning activities was stimulated by the use of learning source, which is the reconstruction result of indigenous knowledge about golobe. Referring to the modified PISA's scientific literacy components, the prospective science teachers enjoyed the learning process for its contextuality. According to Curry \&Ponners (2019), the strength of meaningful learning lays in the learning materials. Moreover, Koretsky et al. (2019) emphasized the importance of empirical learning source. Hence, these arguments support this research's course materials for its empiricism and contextuality, thus attracted the students' willingness to learn. Seen from the assessment results, scientific literacy has already been generated by the time a student wishes to learn about indigenous knowledge.

The prospective science teachers got to know scientific questions after they browsed information on the internet about indigenous knowledge, and it was not limited to the golobe plant. This activity was carried out to emerge curiosity, which was the starting point in improving scientific literacy. They looked for valid sources from scientific papers published in either internationally or nationally reputable journals. The sources were collected, studied, and referred to knowing the characteristics of scientific questions. The awareness that not all questions could be scientifically answered has given the students teachers a new insight in 
sorting out references. According to Pedrosade-Jesus et al. (2016), a question could be scientifically answered when the queried object is concrete and empiric.

Moreover, Bielik\&Yarden (2016) argued that scientific queries are introduced by studying examples of questions. This statement could be criticized by the findings of this research as the prospective science teachers did not review the question sample but get to know the scientific questions after analyzing other people's findings. Scientific question literacy through an in-depth search of information becomes a form of channeling curiosity.

The next step is question making about traditional tribes and knowledge that have been analyzed. The exploration activities made use of internet sources and strengthened by interviews and direct observation. A visit to the object of study in the community, in addition to watching the documentary video, has created a more meaningful atmosphere of conservation learning. Interviews with the inlanders revealed the advantage of the plant to cure numerous diseases, and this fact has been believed since decades ago. Its efficacy has emerged the curiosity to reveal its true benefits. This has coincided with Boevé et al. (2017), who elucidated that exploration findings would emerge confidence as knowledge is perceived through discovery activity. Data collected during the exploration stage have been compiled to provide evidence. As the prospective science teachers' scientific literacy improves, they could identify the data needed to reconstruct the indigenous knowledge. Aligned with this, Roberts (2016) stated that empirical evidence arranged systematically would give complete information about a scientific study so that the fact is easily accounted for. Empirical evidence in a knowledge reconstruction is considered necessary to debate various opinions that might arise to question the truthfulness.

The conservation study on natural resources has to take into account laboratory skills. Moreover, Amolins et al. (2015) argued that lab testing outtakes result in correct concepts; therefore, generate trustworthy knowledge. In this study, the prospective science teachers did tests on golobe not only to discover chemical compounds in it but also serve as a process of developing lab work. An interest in the research object, which was obtained from their own effort, would boost their scientific literacy. Similarly, Chang et al. (2011) and Bernhard (2018) ensured that lab testing on a self-discovered object would create systematic and procedural scientific work.

The examined scientific literacy included communicating the results of knowledge reconstruction. Communication, in this research, was built from information gathering, lab testing, and discovering new scientific knowledge. A set of activities in reconstructing knowledge has given an indepth and broad insight to the prospective science teachers to instill a proper communication skill. Kulgemeyer (2018) and John (2018) described favorable communication skills as a description of the systematic science process. This communication skill has to be supported by a remarkable demonstration skill, which becomes the benchmark of a person's understanding of science concepts derived from the knowledge reconstruction.

A reflection of the conservation course, which made use of the learning materials as a result of indigenous knowledge reconstruction, has revealed the weakness of this research. The flaw was that not all of the prospective science teachers participated in a direct exploration of the golobe. Instead, they referred to the results of interviews, photos, and videos about the golobe. This absence on the direct exploration of the object, according to the prospective science teachers, has caused a restriction in delving certain information about the golobe.

\section{CONCLUSION AND RECOMMENDATION}

The tradition of consuming Golobe is found as a genuine knowledge of the people in the hinterland of Maluku. The test results 
have been used as conservation teaching materials, on the topic of conservation of natural resources for prospective science teachers. They have owned seven components of scientific literacy after using integrated teaching materials resulting from the reconstruction of indigenous knowledge about Golobe. Science learning activities starting from gathering information to laboratory testing, are appropriate when used to develop the scientific literacy of prospective teachers. Reconstruction of indigenous knowledge as teaching materials is a part of conserving endangered natural resources so that it can be expanded to other tribes' indigenousknowledge so that no natural resource of a nation is lost.

\section{REFERENCES}

Allchin, D. (2014). From science studies to scientific literacy: A view from the classroom. Science \& Education, 23(9), 1911-1932.

Amolins, M. W., Ezrailson, C. M., Pearce, D. A., Elliott, A. J., \&Vitiello, P. F. (2015). Evaluating the effectiveness of a laboratory-based professional development program for science educators. Advances in physiology education, 39(4), 341351.doi:10.1152/advan.00088.

Archer-Bradshaw, R. E. (2017). Teaching for scientific literacy? An examination of instructional practices in secondary schools in Barbados. Research in Science Education, 47(1), 67-93.

Arikunto, S. (2012). ProsedurPenelitian: SuatuPendekatanPraktek. EdisiRevisi. Jakarta: PT. RinekaCipta.

Bernhard, J. (2018). What matters for students' learning in the laboratory? Do not neglect the role of experimental

equipment!. Instructional

Science, 46(6), $819-$ 846.https://doi.org/10.1007/s11251018-9469-x.
Bielik, T., \&Yarden, A. (2016). Promoting the asking of research questions in a high-school biotechnology inquiryoriented program. International Journal of STEM Education,3(1), 15.https://doi.org/10.1186/s40594016-0048-x.

Boevé, A. J., Meijer, R. R., Bosker, R. J., Vugteveen, J., Hoekstra, R., \& Albers, C. J. (2017). Implementing the flipped classroom: an exploration of study behaviour and student performance. Higher

Education, 74(6), 10151032.https://doi.org/10.1007/s10734016-0104-y.

Chang, H. P., Chen, C. C., Guo, G. J., Cheng, Y. J., Lin, C. Y., \& Jen, T. H. (2011). The development of a competence scale for learning science: Inquiry and communication. International Journal of Science and Mathematics Education, 9(5), 12131233.https://doi.org/10.1007/s10763010-9256-x.

Chaudhuri, B. (2015). Science in society: challenges and opportunities for indigenous knowledge in the presentday context. Global Bioethics, 26(2), 78-

85.DOI:10.1080/11287462.2015.10371 40.

Curry, J. H., \&Ponners, P. J. (2019). The Meaningful Integration of Emerging Learning

Technologies. TechTrends, 63(1), 23.https://doi.org/10.1007/s11528-0180371-9.

Ghosh, S., Chakraborty, R., \&Raychaudhuri, U. (2015). Determination of $\mathrm{pH}$-dependent antioxidant activity of palm (Borassusflabellifer) polyphenol compounds by photoluminol and DPPH methods: a comparison of redox reaction sensitivity. 3 Biotech, 5(5), 633- 
640.https://doi.org/10.1007/s13205014-0260-7.

Groves, C. (2019). Sustainability and the future: reflections on the ethical and political significance of sustainability. Sustainability

Science, 14(4), $915-$ 924.https://doi.org/10.1007/s11625019-00700-0.

H ng, N. V. T., Bulte, A. M. W., \& Pilot, A. (2017). Interaction of Vietnamese teachers with a social constructivismbased primary science curriculum in a framework appropriate for a Confucian heritage culture. AsiaPacific Science Education, 3(1), 2.

Hanuscin, D. L., \&Zangori, L. (2016). Developing practical knowledge of the Next Generation Science Standards in elementary science teacher education. Journal of Science Teacher Education, 27(8), 799818.https://doi.org/10.1007/s10972016-9489-9.

Higgins, M., \& Kim, E. J. A. (2019). De/colonizing methodologies in science education: rebraiding research theory-practice-ethics with Indigenous theories and theorists. Cultural Studies of Science Education, 14(1), 111-127.

Hsieh, F. P., Lin, H. S., Liu, S. C., \& Tsai, C. Y. (2019). Effect of Peer Coaching on Teachers' Practice and Their Students' Scientific Competencies. Research in Science Education, 1 24.https://doi.org/10.1007/s11165019-9839-7.

Hwang, J., Choi, K. M., Bae, Y., \& Shin, D. H. (2018). Correction to: Do Teachers' Instructional Practices Moderate Equity in Mathematical and Scientific Literacy?: An Investigation of the PISA 2012 and 2015. International Journal of Science and Mathematics Education, 16(8),
$1629-$

1631.https://doi.org/10.1007/s10763018-9918-7.

Inventado, P. S., Scupelli, P., Ostrow, K., Heffernan, N., Ocumpaugh, J., Almeda, V., \& Slater, S. (2018). Contextual factors affecting hint utility. International journal of STEM education, 5(1),

13.https://doi.org/10.1186/s40594018-0107-6.

John, S. (2018). Scientific Deceit. Synthese. https://doi.org/10.1007/s11229-01802017-4.

Khodabande, Z., Jafarian, V. \& Sariri, R. (2017). Antioxidant activity of Chelidonium majus extract at phenological stages. Appl Biol Chem, 60, 497-503.

https://doi.org/10.1007/s13765-0170304-x

Koretsky, M. D., Vauras, M., Jones, C., liskala, T., \&Volet, S. (2019). Productive disciplinary engagement in High-and Low-Outcome student groups: Observations from three collaborative science learning contexts. Research in Science Education, 1 24.https://doi.org/10.1007/s11165019-9838-8.

Kulgemeyer, C. (2018). Impact of secondary students' content knowledge on their communication skills in science. International Journal of Science and Mathematics Education, 16(1), $89-$ 108.https://doi.org/10.1007/s10763016-9762-6.

Masoko, P., \&Makgapeetja, D. M. (2015). Antibacterial, antifungal and antioxidant activity of Oleaafricana against pathogenic yeast and nosocomial pathogens. BMC complementary and alternative medicine, 15(1), 409- 
407.https://doi.org/10.1186/s12906015-0941-8.

Ntuli, H., Jagers, S. C., Linell, A., Sjöstedt, M., \&Muchapondwa, E. (2019). Factors influencing local communities' perceptions towards conservation of transboundary wildlife resources: the case of the Great Limpopo Trans-frontier Conservation Area. Biodiversity and Conservation, 28(11), 2977-3003. https://doi.org/10.1007/s10531-01901809-5

Odeja, O., Ogwuche, C. E., Elemike, E. E., \& Obi, G. (2017). Phytochemical screening, antioxidant and antimicrobial activities of Acalyphaciliata plant. Clinical Phytoscience, 2(1), 12. https://doi.org/10.1186/s40816-0160027-2.

Parmin, P., Sajidan, S., Ashadi, A., Sutikno, S., \&Fibriana, F. (2017). Science integrated learning model to enhance the scientific work independence of student teacher in indigenous knowledge transformation. JurnalPendidikan IPA Indonesia, 6(2), 365-372.

Pedrosa-de-Jesus, H., Leite, S., \& Watts, M. (2016). 'Question Moments': A Rolling Programme of Question Opportunities in Classroom Science. Research in Science Education, 46(3), 329341.https://doi.org/10.1007/s11165014-9453-7.

Rhee, H. Y., \& Choi, K. (2014). Development and implementation of science and technology ethics education program for prospective science teachers. Science \& Education, 23(5), 11011130.https://doi.org/10.1007/s11191013-9644-z.

Roberts, R. (2016). Understanding the validity of data: a knowledge-based network underlying research expertise in scientific disciplines. Higher Education, 72(5), 651-668.

Robbins, J. A., \& Dewar, J. (2011). Traditional Indigenous approaches to healing and the modern welfare of traditional knowledge, spirituality and lands: A critical reflection on practices and policies taken from the Canadian Indigenous example. The International Indigenous Policy Journal, 2(4), 2.

Ryan, A. (2008). Indigenous Knowledge in the Science Curriculum: Avoiding Neo-Colonialism. Cultural Studies of Science Education, 3 (3): 663-702.

She, H.C., Stacey, K. \& Schmidt, W.H. (2018). Science and Mathematics Literacy: PISA for Better School Education. International Journal of Science and Mathematics Education, 16 (1): 1-5.

Sukri, A. M. A. Rizka, H. G. Sakti, K.l U. Maududy, G. \&Hadiprayitno. (2018). Designing an Integrated Curriculum Based on Local Primacy and Social Reconstruction Perspectives of West Nusa Tenggara, Indonesia. JurnalPendidikan IPA Indonesia, 7(4): 467-475.

Sugiyono. 2008. Metode Penelitian Kuantitatif, Kualitatif dan $R \& D$. Bandung: ALFABETA.

Talafian, H., Moy, M.K., \& Woodard, M.A. (2019). STEM Identity Exploration through an Immersive Learning Environment. Journal for STEM Education Research,

Trauth-Nare, A. (2016). Re-envisioning Scientific Literacy as Relational, Participatory Thinking and Doing. Cultural Studies of Science Education, 11 (2): 327-334.

Vass, G., Lowe, K., Burgess, C. (2019). Correction to: The Possibilities and Practicalities of Professional Learning in Support of Indigenous Student 
126 | Volume 27, Number 2, July, 2020, Page 115-126

Experiences in Schooling: A Systematic Review. The Australian Educational Researcher, 46(2): 363364.

Wang, CJ., Wan, JZ., \& Zhang, GM. (2016). Erratum to: Protected Areas May not Effectively Support Conservation of Endangered Forest Plants Under Climate Change. Environmental Earth Sciences, 75: 803. https://doi.org/10.1007/s12665016-5578-5

Woro, S., Sudarmin, Wiyanto, \&Supartono. (2016). The Reconstruction of Society
Indigenous Science into Scientific Knowledge in the Production Process of Palm Sugar. Journal of Turkish Science Education. 13 (4): 281-292.

Wyborn, C., van Kerkhoff, L., \& Dunlop, M. (2016). Future Oriented Conservation: Knowledge Governance, Uncertainty and Learning. Biodiversity and Conservation, 25(7): 1401-1408.

Yarden, A. (2009). Reading Scientific Texts: Adapting Primary Literature for Promoting Scientific Literacy. Research in Science Education, 39 (3): 307-3011. 